\title{
Ischemic Insults Derepress the Gene Silencer REST in Neurons Destined to Die
}

\author{
Agata Calderone, Teresa Jover, ${ }^{\star}$ Kyung-min Noh,${ }^{\star}$ Hidenobu Tanaka, ${ }^{\dagger}$ Hidenori Yokota, Ying Lin, Sonja Y. Grooms, \\ Roodland Regis, Michael V. L. Bennett, and R. Suzanne Zukin \\ Department of Neuroscience, Albert Einstein College of Medicine, Bronx, New York 10461
}

A subset of genes implicated in genetic and acquired neurological disorders encode proteins essential to neural patterning and neurogenesis. The gene silencing transcription factor neuronal repressor element-1 silencing transcription factor (REST)/neuron-restrictive silencer factor (NRSF) plays a critical role in elaboration of the neuronal phenotype. In neural progenitor and non-neural cells, REST acts by repression of a subset of neural genes important to synaptic plasticity and synaptic remodeling, including the AMPA receptor (AMPAR) subunit GluR2. Here we show that global ischemia triggers REST mRNA and protein expression. REST suppresses GluR2 promoter activity and gene expression in neurons destined to die. Because the GluR2 subunit governs AMPAR $\mathrm{Ca}^{2+}$ permeability, these changes are expected to have profound effects on neuronal survival. In keeping with this concept, acute knockdown of the REST gene by antisense administration prevents GluR2 suppression and rescues post-ischemic neurons from ischemia-induced cell death in an in vitro model. To our knowledge, our study represents the first example of ischemia-induced induction of a master transcriptional regulator gene and its protein expression critical to neural differentiation and patterning in adult neurons. Derepression of REST is likely to be an important mechanism of insult-induced neuronal death.

Key words: REST; chromatin remodeling; transcription factors; AMPA receptors; neuronal insult; neuronal death; global ischemia; hippocampus

\section{Introduction}

The gene silencing transcription factor neuronal repressor element-1 (RE1) silencing transcription factor/neuronrestrictive silencer factor (REST/NRSF) is widely expressed during embryogenesis and plays a strategic role in terminal neuronal differentiation (Chong et al., 1995; Schoenherr et al., 1996). In neural progenitor cells and non-neuronal cells, REST actively represses a large array of neural-specific genes important to synaptic plasticity and synaptic remodeling, including synaptic vesicle proteins, structural proteins, voltage-sensitive ion channels, and neurotransmitter receptors (for review, see Schoenherr et al., 1995). Examples are synapsin I (Howland et al., 1991; Li et al., 1993; Schoch et al., 1996), NaCh II (Kraner et al., 1992; Chong et al., 1995), muscarinic acetylcholine $\mathrm{m} 4$ receptor (Wood et al., 1996; Mieda et al., 1997), $\mu$ opioid receptor (Andria and Simon, 2001), SCG10 (Mori et al., 1992), and the neuronal nicotinic acetylcholine receptor subunit $\beta 2$ (Bessis et al., 1995) and AMPA receptor (AMPAR) subunit GluR2 (Myers et al., 1998). As neural progenitors differentiate and migrate out of the ventricular zone, REST downregulation is essential for induction and maintenance

\footnotetext{
Received Aug. 26, 2002; revised Dec. 14, 2002; accepted Dec. 16, 2002.

This work was supported by National Institutes of Health Grants NS20752, NS31282 (R.S.Z.), and NS07512 (M.V.L.B.) and a grant from the F. M. Kirby Foundation. M.V.L.B. is the Sylvia and Robert S. Olnick Professor of Neuroscience. We thank Dr. Anna Francesconi for helpful scientific discussions, Dr. Gail Mandel for the generous gift of REST antibodies, Dr. Tonis Timmusk for the REST riboprobes, and Judy Wong for technical assistance. We acknowledge the Analytical Imaging Facility of the Albert Einstein College of Medicine (Michael Cammer, Director).

*T.J. and K.N. contributed equally to this work.

${ }^{\dagger}$ Deceased, 0ct. 13, 2002. We remember and honor Hidenobu Tanaka for his scientific insight, creativity, technical acumen and his warmth and sensitivity as a human being.

Correspondence should be addressed to Dr. R. Suzanne Zukin, Department of Neuroscience, Albert Einstein College of Medicine, 1300 Morris Park Avenue, Bronx, NY 10461. E-mail: zukin@aecom.yu.edu.

Copyright $\odot 2003$ Society for Neuroscience $\quad 0270-6474 / 03 / 232112-10 \$ 15.00 / 0$
}

of the neural phenotype (Ballas et al., 2001). Consistent with this idea, REST is required for mouse viability (Chen et al., 1998), and overexpression of REST in differentiating neurons disrupts neuronal gene expression and increases axon-guidance errors $(\mathrm{Pa}-$ quette et al., 2000).

Recent studies have advanced our understanding of the molecular underpinnings of REST-dependent silencing of target genes, including GluR2. REST is a member of the Gli-Krüppel family of zinc-finger transcriptional repressors and contains nine noncanonical zinc finger motifs through which it binds the cisacting RE1 within the promoter region of target genes (Chong et al., 1995; Schoenherr et al., 1996). REST associates with the corepressors $\operatorname{Sin} 3 \mathrm{~A}$ and coREST, which in turn recruit histone deacetylase to the promoters of target genes (Ballas et al., 2001). The co-repressor complex silences gene transcription by deacetylation of core histone proteins and tightening of the core chromatin complex, thus restricting access of the transcription machinery required for gene activation. Chromatin remodeling is a universal mechanism of transcriptional repression and is implicated in other histone-modulated processes, including DNA replication, recombination, and repair (for review, see Chen et al., 2001).

AMPARs mediate fast synaptic transmission at excitatory synapses and play important roles in synaptic remodeling, activitydependent synaptic plasticity, and excitotoxic cell death. The GluR2 subunit governs a number of biophysical properties of AMPARs, including $\mathrm{Ca}^{2+}$ permeability (Hollmann et al., 1991; Verdoorn et al., 1991; Burnashev et al., 1992), voltage-dependent block by intracellular polyamines (Bowie and Mayer, 1995; Donevan and Rogawski, 1995), single-channel conductance (Swanson et al., 1997), and activity-dependent AMPAR recycling 
and targeting to the synapse (Liu and Cull-Candy, 2000; Passafaro et al., 2001). Thus, an acute change in the level of GluR2 expression would be expected to have profound effects on synaptic activity and neuronal survival. The relative expression of GluR2 in neurons is not static but is regulated in a cell-specific manner during development (Pellegrini-Giampietro et al., 1991) and remodeled by activity (Liu and Cull-Candy, 2000), antipsychotics (Fitzgerald et al., 1995), drugs of abuse (Fitzgerald et al., 1996), and corticosteroids (Nair et al., 1998), and after seizures (Pollard et al., 1993; Friedman et al., 1994; Prince et al., 1995) or ischemic insult (Gorter et al., 1997).

A subset of genes implicated in genetic and acquired neurological disorders encode proteins essential to neural patterning and neurogenesis (Mehler and Gokhan, 2001). A hallmark of these disorders is their delayed onset and high cell specificity of neuronal death. Transient global ischemia associated with cardiac arrest induces delayed, cell-specific death of hippocampal CA1 pyramidal neurons (Tanaka et al., 2002). The substantial delay between ischemic insult and onset of cell death is consistent with a role for transcriptional changes. Ischemia triggers suppression of GluR2 expression in vulnerable CA1 neurons. Because the GluR2 gene is a known target of REST (Huang et al., 1999) and is implicated in AMPAR-mediated excitotoxic cell death (Tanaka et al., 2000), these observations implicate REST as a candidate mediator of ischemia-induced transcriptional changes including suppression of GluR2.

The present study was undertaken to examine the hypothesis that induction of REST contributes to global ischemia-induced neuronal death. Here we show that global ischemia triggers expression of REST and suppresses GluR2 promoter activity and gene expression in neurons destined to die. In a slice culture model, acute knockdown of the REST gene rescues post-ischemic neurons from ischemia-induced cell death, indicating a causal relation between REST expression and neuronal death. Thus ischemic insults derepress injury-induced derepression of a gene implicated as a master regulator of the neuronal phenotype.

\section{Materials and Methods}

Global ischemia. Age-matched, adult male Sprague Dawley rats (Charles River Laboratories, Wilmington, MA), weighing 100-125 gm, were maintained in a temperature- and light-controlled environment with a $14 \mathrm{hr}$ light/10 hr dark cycle and were treated in accordance with the principles and procedures of the National Institutes of Health Guidelines for the Care and Use of Laboratory Animals. Rats were fasted overnight and on the day of surgery were subjected to sham operation (control animals), global ischemia, or ischemic preconditioning by four-vessel occlusion according to Pulsinelli and Brierley (1979). In brief, animals were anesthetized with halothane (induction, 2\%; maintenance, $0.5-$ $1 \%)$. The vertebral arteries were subjected to electrocauterization; common carotid arteries were exposed and isolated with a 3-0 silk thread, and the wound was sutured. Twenty-four hours later, the wound was reopened and carotid arteries were occluded (10 min for global ischemia or $4 \mathrm{~min}$ for ischemic preconditioning), followed by reperfusion. Arteries were visually inspected to ensure adequate reflow, and then anesthesia was discontinued. For sham operation, animals were subjected to the same anesthesia and surgical procedures, except that the carotid arteries were not occluded. Body temperature was maintained at $37^{\circ} \mathrm{C}$ with a rectal thermistor and heat lamp during and after the induction of global ischemia.

Histology. Neuronal damage was assessed by histological examination of brain sections at the level of dorsal hippocampus from animals killed by decapitation at $24 \mathrm{hr}$ after sham operation, at $48 \mathrm{hr}$ after preconditioning, or at 12,24, and $48 \mathrm{hr}$ after global ischemia. Animals were fixed by transcardiac perfusion with paraformaldehyde (4\%) under deep anesthesia. Brains were removed and immersed in fixative (overnight at $\left.4^{\circ} \mathrm{C}\right)$. Coronal sections $(15 \mu \mathrm{m})$ were cut with a cryotome and stained with toluidine blue.

In situ hybridization. To detect REST mRNA expression in the hippocampus of control and experimental animals, animals were anesthetized with pentobarbital and killed by decapitation at $24 \mathrm{hr}$ after sham operation, at $48 \mathrm{hr}$ after preconditioning, or at 12, 24, and $48 \mathrm{hr}$ after global ischemia, or (for preconditioned animals) at $48 \mathrm{hr}$ after ischemic preconditioning, followed by global ischemia. REST mRNA expression was assessed by in situ hybridization. Serial coronal sections or freshfrozen rat brain at the level of the dorsal hippocampus was hybridized with $\left[{ }^{35} \mathrm{~S}\right.$ ]-labeled riboprobes directed to rat REST (rREST), riboprobe 4 (a $460 \mathrm{bp}$ fragment encoding the region upstream of zinc finger 1 through zinc finger 2 within the N-terminal domain of REST) or riboprobe 11 (a $360 \mathrm{bp}$ fragment encoding the region upstream of zinc finger 9 within the C-terminal domain of REST) (Palm et al., 1998). GluR2 mRNA expression was assessed by in situ hybridization as described (Tanaka et al., 2002). In brief, coronal sections of rat brain at the level of the dorsal hippocampus were probed with a full-length, $\left[{ }^{35} \mathrm{~S}\right] \mathrm{UTP}$ labeled RNA probe to GluR2 cDNA. RNA probes were transcribed by incubation of the corresponding cDNA $\left(1 \mathrm{hr}\right.$ at $\left.37^{\circ} \mathrm{C}\right)$ with $\mathrm{T} 3$ polymerase (REST) or T7 polymerase (GluR2) in the presence of $\left[{ }^{35}\right.$ S ]UTP using a Stratagene transcription kit. Radiolabeled probes were purified by phe$\mathrm{nol} /$ chloroform extraction. Film autoradiograms were quantitated as described (Tanaka et al., 2002).

Immunolabeling. To examine effects of global ischemia on patterns of REST expression, animals were killed at 12, 24, and $48 \mathrm{hr}$ after global ischemia or at $24 \mathrm{hr}$ after sham operation. Brains were rapidly removed, frozen by immersion in 2-methylbutane at $-42^{\circ} \mathrm{C}$, and stored at $-70^{\circ} \mathrm{C}$ until sectioning. Brains were cut into sections $(18 \mu \mathrm{m})$ in the coronal plane of the dorsal hippocampus by cryotome and thaw mounted onto glass slides. Sections were fixed (4\% paraformaldehyde), blocked, and probed with anti-REST antibodies $\mathrm{p} 73$, a polyclonal antibody directed to the N-terminal zinc-finger DNA binding domain of the REST protein, or F3, a polyclonal antibody directed to the ninth zinc finger within the C-terminal domain of REST [1:1000, overnight at $4^{\circ} \mathrm{C}$; gifts of Dr. Gail Mandel, State University of New York, Stony Brook, NY (Chong et al., 1995)], followed by biotinylated goat anti-rabbit IgG (1:200; $1 \mathrm{hr}$ at room temperature Vector Laboratories, Burlingame, CA). Sections were incubated and processed with avidin-biotin complex (Vectastain ABC kit, Vector Labs) (1 hr at room temperature), followed by 3-3'diaminobenzidine (Vector Labs). For immunolabeling of cultured hippocampal slices, slices were fixed and probed with the $\mathrm{N}$-terminal antibody $\mathrm{p} 73$ and secondary antibody as above, followed by fluoresceinavidin (1:500, $1 \mathrm{hr}$ at room temperature; Vector Labs). Images were viewed through a Nikon inverted microscope ECLIPSE TE300, and images were acquired with a SPOT RT CCD-cooled camera with diagnostic software version 3.0.

Western blot analysis. To examine the effects of global ischemia on REST and GluR2 protein abundance, Western blot analysis was performed on protein samples isolated from hippocampal subfields of experimental and control animals at 24 and $48 \mathrm{hr}$ after global ischemia as described (Opitz et al., 2000). Transverse slices of dorsal hippocampus (1 $\mathrm{mm}$ ) were cut with a Mcllwain tissue chopper. The CA1, CA3, and DG subfields were rapidly microdissected and homogenized in sample buffer containing phenylmethylsulfonyl fluoride $(1 \mathrm{~mm})$, and nuclear and cytosolic fractions were isolated by differential centrifugation using a commercially available kit (Pierce, Rockford, IL). As a positive control, protein samples were prepared from primary cultures of astrocytes from the brains of embryonic day 18 rats at $30 \mathrm{~d}$ in culture, as described (Fan et al., 1999). Protein concentration was measured using a bicinchoninic acid protein assay (Pierce). Aliquots of protein extract (10 $\mu \mathrm{g}$ of total protein for GluR2 or $80 \mu \mathrm{g}$ of total protein for REST) were separated by gel electrophoresis on 10\% (GluR2) or 7.5\% (REST) polyacrylamide gels. Bands were transferred to a nitrocellulose membrane for immunoblotting with an antibody directed to the N-terminal domain of REST (see above) or with an anti-GluR2 monoclonal antibody directed to a sequence within the N-terminal domain of the GluR2 subunit (1:1000; PharMingen, San Diego, CA). The purity of the subcellular fractions was verified with an antibody against the nuclear protein PARP (H-250; 
Santa Cruz Biotechnology, Santa Cruz CA). For GluR1 and GluR2 protein expression, band intensities were normalized to those for actin, which was used as a loading control. In the case of REST protein expression in nuclear and cytosolic fractions of CA1 tissue, we performed equal loading of samples, because actin is not expressed in nuclear tissue. In addition, band densities of samples from experimental animals were normalized to the corresponding control values on the same film to enable comparisons of blots apposed to different films.

Chromatin immunoprecipitation assays. The levels of acetylated $\mathrm{H} 3$ and $\mathrm{H} 4$ histones physically associated with the endogenous GluR2 promoter were assayed by the chromatin immunoprecipitation (ChIP) assay according to the protocol provided by the manufacturer (anti-acetyl $\mathrm{H} 3$ and anti-acetyl H4 ChIP assay kits; Upstate Biotechnology, Rochester, NY) as described (Huang et al., 1999). Transverse slices of dorsal hippocampus $(1 \mathrm{~mm})$ from the brains of control and experimental animals were cut with a Mcllwain tissue chopper and immersed in 1\% formaldehyde ( $2 \mathrm{hr}$ at room temperature) to cross-link histone proteins to DNA. The CA1 and CA3 subfields were microdissected, and cell lysates were prepared and sonicated to afford chromosomal DNA in the range of $0.2-3 \mathrm{~kb}$. Antibodies directed against acetylated $\mathrm{H} 3$ and $\mathrm{H} 4$ histone proteins were used to immunoprecipitate chromatin, and immunocomplexes were collected on protein G-agarose beads. After washes and elution, DNA was released from histones, treated with proteinase $\mathrm{K}$, and purified by phenol-chloroform extraction and ethanol precipitation. To monitor the relative abundance of GluR2 promoter physically associated with acetylated histone, DNA samples were used as templates for PCR with GluR2-specific primers to amplify a GluR2 genomic DNA fragment in the core of the GluR2 promoter $(-43$ to +103 relative to the transcription start site). As standards, samples of genomic DNA (10, 50, or $250 \mathrm{ng})$ were also amplified by PCR. PCR products were subjected to electrophoresis on $2 \%$ ethidium bromide-stained gels.

Slice culture and antisense administration. Organotypic hippocampal slice cultures were prepared as described (Stoppini et al., 1991). In brief, hippocampi were removed from the brains of 7- to 9-d-old Wistar rats and placed in ice-cold HBSS supplemented with glucose $(5 \mathrm{mg} / \mathrm{ml})$ and sucrose $(7 \mathrm{mg} / \mathrm{ml})$. Transverse slices $(400 \mu \mathrm{m})$ were cut with a McIlwain tissue chopper and transferred to humidified semiporous membranes (30 mm Millicell-CM tissue culture plate inserts; four slices per membrane), placed in six-well tissue culture plates containing $1.2 \mathrm{ml}$ of culture medium (50\% Eagle's MEM, 25\% heat-inactivated horse serum, $25 \%$ HBSS, $5 \mathrm{mg} / \mathrm{ml}$ glucose, and $1 \mathrm{~mm}$ glutamine), and maintained $\left(37^{\circ} \mathrm{C}\right.$ in $95 \%$ air $\left./ 5 \% \mathrm{CO}_{2}\right)$ for $14 \mathrm{~d}$ in vitro. To induce oxygen glucose deprivation (OGD), slices were exposed to serum-free, glucose-free medium saturated with $95 \% \mathrm{~N}_{2} / 5 \% \mathrm{CO}_{2}\left(45 \mathrm{~min}\right.$ at $\left.37^{\circ} \mathrm{C}\right)$ in an airtight anoxic chamber (Billups-Rothenberg, Del Mar, CA). After OGD, slices were returned to oxygenated, glucose-containing culture medium containing propidium iodide $(5 \mu \mathrm{g} / \mathrm{ml}$ ) (Molecular Probes, Eugene OR) under normoxic conditions until evaluation of neuronal injury.

Oligomer phosphodiester antisense oligodeoxynucleotides (15 mers) were designed to target the rat REST mRNA: antisense 1 , complementary to nucleotides 462-476 (5'-CGGAAGGGTTTGGCC-3'), antisense 2, complementary to nucleotides 1596-1610 (5'-GGATGGGCCTCGGCG-3'), and antisense 3, complementary to nucleotides 2891-2905 (5'TAGGAGGGGAGGCCA-3') of rat REST mRNA (GenBank accession number NM031788). Filter-sterilized antisense, sense (5'-GGCCAAACCCTTCCG-3') and missense (5'-GTCGTTGGCGGAGCA-3') oligodeoxynucleotides $(20 \mu \mathrm{M})$ were added into the culture medium immediately after OGD and maintained for $72 \mathrm{hr}$. Oligodeoxynucleotide sequences exhibited no significant similarity to any other known mammalian genes by a BLAST (Basic Local Alignment Search Tool, a program for searching DNA sequence databases) search.

\section{Results}

Global ischemia triggers REST mRNA expression in CA1 pyramidal neurons

To examine the hypothesis that neuronal insults trigger induction of REST in neurons destined to die, we induced global ischemia in adult rats and examined REST mRNA expression in the
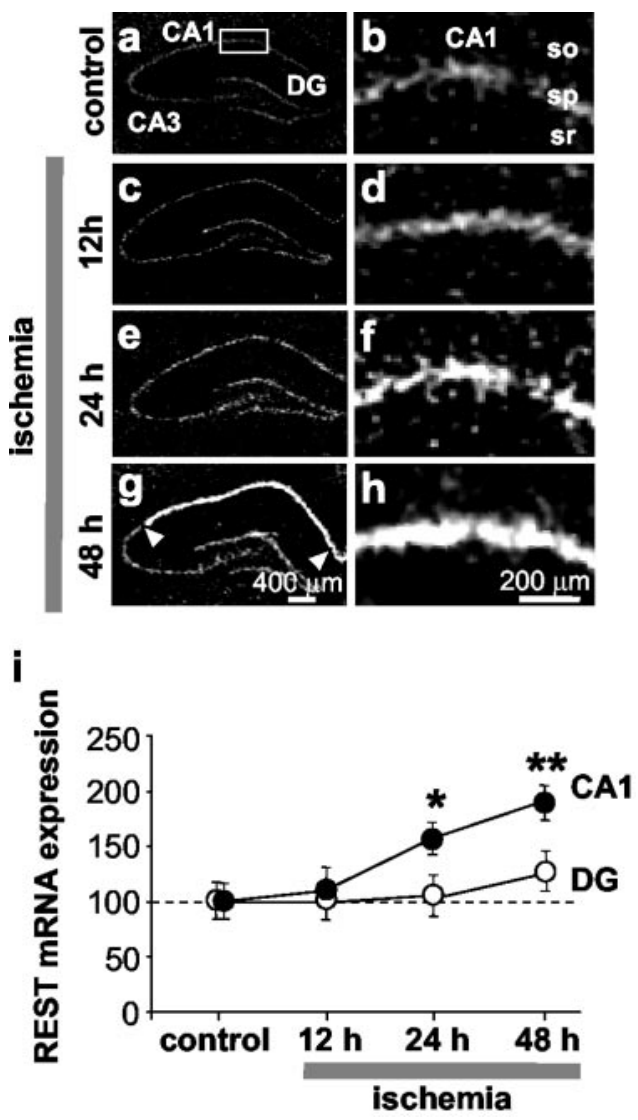

Figure 1. Global ischemia increases REST mRNA expression in CA1 pyramidal neurons. $a-h$, Film autoradiograms of REST mRNA expression detected by in situ hybridization with "riboprobe 11 " (see Material and Methods) of brain sections at the level of the dorsal hippocampus from control $(a, b ; n=3)$ and experimental rats at $12 \mathrm{hr}(c, d ; n=9), 24 \mathrm{hr}(e, f ; n=8)$, and $48 \mathrm{hr}$ $(g, h ; n=12)$ after global ischemia. $i$, Quantitative analysis of REST mRNA expression in the CA1 (CA1) pyramidal cell layer (O) and the dentate gyrus (DG) granule cell layer (O). At $24 \mathrm{hr}$ after ischemia, REST mRNA expression was increased significantly in the CA1 pyramidal cell layer and slightly, but not significantly, increased in the DG granule cell layer. At $48 \mathrm{hr}$, REST was dramatically increased in the CA1 (arrowheads), with significantly lower expression in DG and CA3 (data not analyzed, but see autoradiograms). Experiments performed with "riboprobe 4" (see Material and Methods) showed similar results. Mean optical density values are reported after normalization to the control value for the corresponding subfield. Statistical significance was assessed by ANOVA followed by Newman-Keuls test $\left({ }^{*} p<0.05\right.$; $\left.{ }^{* *} p<0.01\right)$. Scale bars: $a, c, e$, $g, 400 \mu \mathrm{m} ; b, d, f, h, 200 \mu \mathrm{m}$. so, Stratum oriens; sp, stratum pyramidale; sr, stratum radiatum.

hippocampus by in situ hybridization. Global ischemia in rats provides a well established model of neuronal insult in which neuronal death is specific to CA1 pyramidal neurons and delayed by 3-4 d, allowing examination of the molecular mechanisms that underlie cell death. In control hippocampus, REST mRNA expression was low but was spatially concentrated in the pyramidal cell layers of CA1 and CA3 and granule cell layer of dentate gyrus (Fig. $1 a, b$ ). In contrast, the stratum radiatum and stratum oriens, which contain the apical and basilar dendrites of the pyramidal neurons, exhibited little or no signal (Fig. 1b). Because the stratum pyramidale of CA1 contains a nearly homogeneous $(>95 \%)$ population of pyramidal neurons, this finding indicates that principal neurons of the hippocampus constitutively express REST mRNA at low abundance, but it does not rule out the possibility that inhibitory interneurons and astroglia, which are interspersed throughout the molecular and dendritic layers, express REST mRNA. Experiments in which in situ hybridization was performed with a "sense" probe showed essentially no signal; this finding indicates specificity of the hybridization technique. 


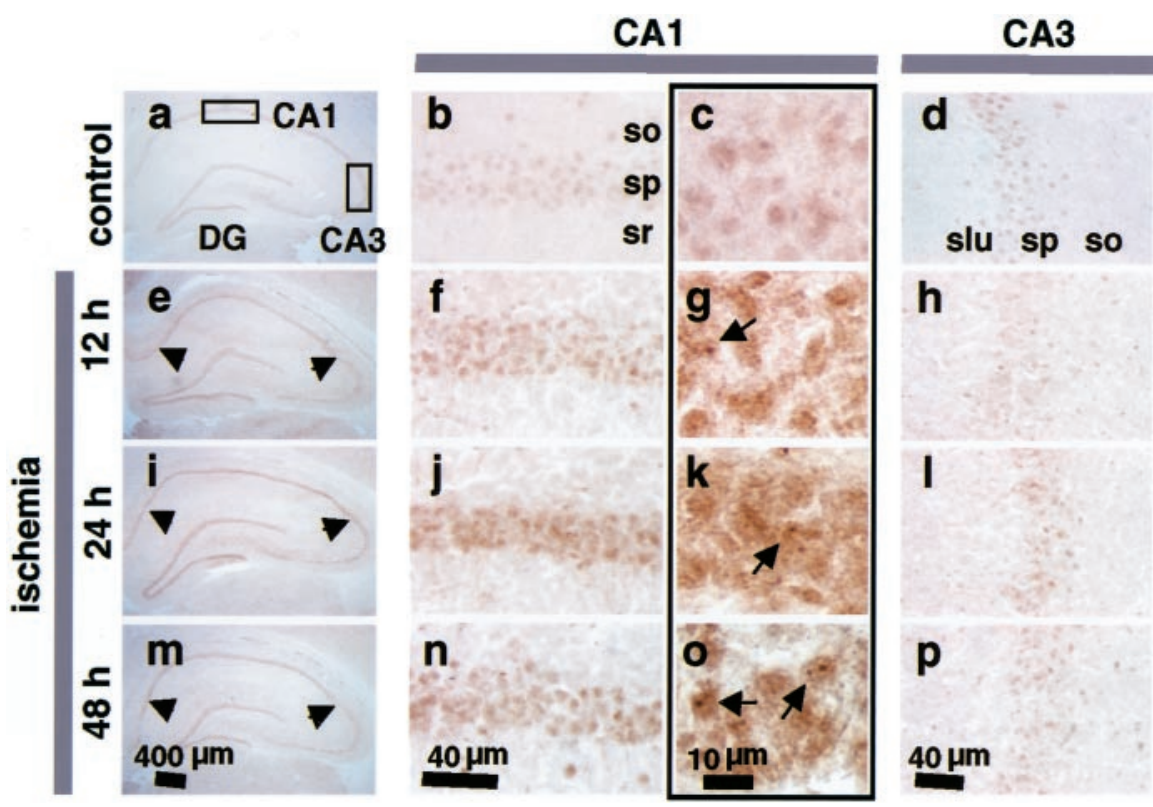

Figure 2. Ischemia increases REST protein expression in nuclei of CA1 pyramidal neurons. Coronal sections of rat brain at the level of the dorsal hippocampus were probed with the $\mathrm{p} 73$ antibody, a polyclonal antibody directed to the $\mathrm{N}$-terminal DNA binding domain of REST. Representative sections are shown from control ( $a-d)$ and experimental animals at $12 \mathrm{hr}(e-h), 24 \mathrm{hr}(i-l)$, and $48 \mathrm{hr}(m-p)$ after global ischemia ( $n=5$ per treatment group). REST immunolabeling in the entire hippocampus is shown at low magnification ( first column), in the CA1 at intermediate (second column) and high magnification (third column), and in the CA3 at intermediate magnification (fourth column). Arrowheads point to the CA1 pyramidal cell layer $(e, i, m)$. Arrows point to the nuclei of post-ischemic CA1 neurons $(g, k, 0)$. so, Stratum oriens; $s p$, stratum pyramidale; $s r$, stratum radiatum; slu, stratum lucidum. Scale bars: $a, e, i, m, 400 \mu \mathrm{m} ; b, d, f, h, j, l, n, p, 40 \mu \mathrm{m} ; c, g, k, 0,10 \mu \mathrm{m}$. sional scattered cells within the apical and basilar dendrite layers of the stratum radiatum and stratum oriens of CA1 (Fig. $2 b$ ) and the stratum lucidum and stratum oriens of CA3 (Fig. 2d). These layers are interspersed with astroglia, which express REST (Fig. 3), and inhibitory interneurons, which express GluR2 at low abundance and therefore might express REST in the differentiated state. Experiments in which immunolabeling was performed in the absence of primary antibody showed essentially no immunolabeling; this finding indicates specificity of the technique.

Global ischemia induced a pronounced increase in REST protein selectively in pyramidal neurons of the CA1 (Fig. 2). REST protein expression was significantly increased in CA1 neurons at 12 $\mathrm{hr}$ (the earliest time point examined) (Fig. $2 e-g)$ and was further increased at $24 \mathrm{hr}$ (Fig. $2 i-k$ ) and $48 \mathrm{hr}$ (Fig. $2 m-o$ ) after ischemia. High-magnification images of postischemic hippocampus revealed that REST protein expression was concentrated in the nuclei of CA1 pyramidal cells, although labeling extended into the surrounding cytoplasm (Fig. 2g,k,o). The ischemia-induced increase in REST protein was cell specific in that REST was not detectably altered in CA3
Global ischemia induced a marked upregulation of REST mRNA specifically in CA1 pyramidal neurons (Fig. $1 c-h$ ). At 12 $\mathrm{hr}$, the increase in REST was marginal and did not achieve statistical significance. The increase in REST mRNA expression in the pyramidal cell layer of CA1 was pronounced at $24 \mathrm{hr}$ (to $158 \pm$ $13.01 \%$ of control; $n=4 ; p<0.05 ; n=8$ ) (Fig. $1 e, f, i)$ and at 48 hr (to $184 \pm 15.64 \%$ of control; $p<0.01 ; n=12$ ) (Fig. $1 g, h, i$ ). The ischemia-induced increase in REST mRNA was cell specific in that it was not significantly altered in granule cells of the dentate gyrus (Fig. 1c,e,g,i) or in pyramidal neurons of the CA3 (Fig. $1 c, e, g)$. These findings indicate that the upregulation of REST mRNA is confined to neurons destined to die.

\section{REST protein expression exhibits nuclear localization in post-ischemic CA1 neurons}

To determine whether neurons express REST protein and whether ischemic insults alter REST protein expression, we examined REST protein expression by two methods: immunolabeling, which affords information about the cellular and subcellular distribution of REST, and Western blot analysis, which affords quantitative information about REST protein abundance in subcellular fractions. REST immunolabeling was performed on brain sections from control and experimental animals probed with an antibody that recognizes the N-terminal DNA binding domain of REST or with an antibody that recognizes the ninth zinc finger contained within the C-terminal domain of REST. In control hippocampus, REST protein detected with the N-terminal REST antibody was at low abundance and spatially focused in the pyramidal cell layers of CA1 and CA3 and in the granule cell layer of dentate gyrus (Fig. $2 a-d$ ). This finding suggests that principal neurons of the hippocampus constitutively express low levels of REST protein. In addition to localization within the molecular layers, REST immunolabeling was also observed in occa- a

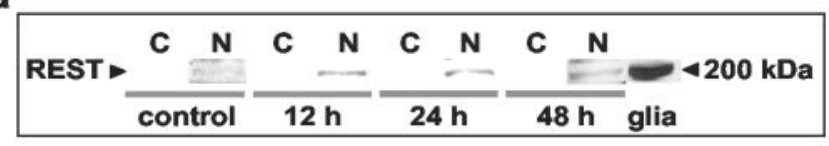

b

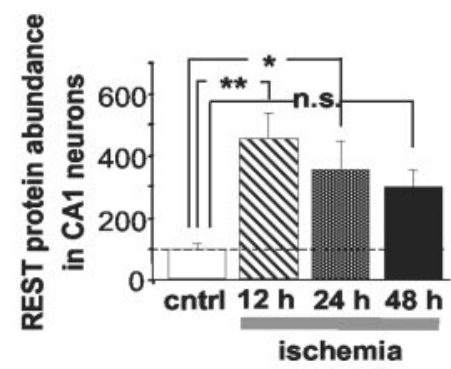

Figure 3. Ischemia increases REST protein abundance in CA1 cell nuclei. $a, b$, REST expression in cytosolic ( $C$ ) and nuclear $(N)$ protein samples isolated from CA1 of control and ischemic animals, as assessed by Western blot analysis. $a$, Representative Western blots probed with the N-terminal antibody (see Material and Methods); $b$, REST abundance for protein samples isolated from the CA1 of control and experimental rats at 12, 24, and $48 \mathrm{hr}$ after global ischemia ( $n=5$ per time point). Equal loading was performed to ensure that the same amount of protein was loaded in each lane. REST protein was at low abundance in samples of control CA1. Ischemia increased REST abundance in CA1 nuclei at 12, 24, and $48 \mathrm{hr}$ after insult. A sample from cultured rat brain astrocytes was used as a positive control. Bars represent means \pm SEMs. Statistical significance was assessed by means of an ANOVA followed by Newman-Keuls test $\left({ }^{*} p<0.05 ;{ }^{* *} p<0.01\right)$.

pyramidal cells of experimental animals as late as $48 \mathrm{hr}$ after ischemia (Fig. $2 d, h, l, p$ ). However, global ischemia induced a slight, transient increase in REST expression in dentate gyrus granule neurons, which survive after ischemia (Fig. 2i). Experiments performed with an antibody directed to the C-terminal domain of the REST protein showed similar spatial and temporal patterns of REST expression. 


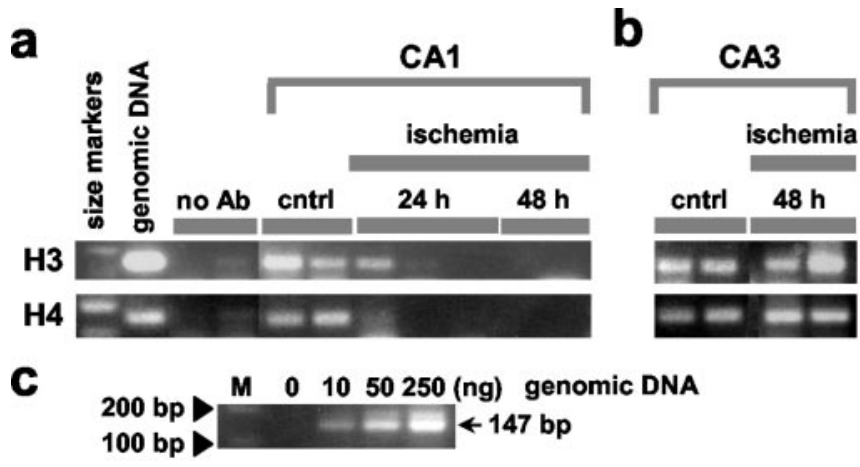

Figure 4. Global ischemia reduces acetylated histone proteins $\mathrm{H} 3$ and $\mathrm{H} 4$ over the GluR2 promoter. Microdissected tissues from the CA1 ( $a$ ) and CA3 (b) of control and experimental animals at 24 and $48 \mathrm{hr}$ after ischemia were subjected to chromatin immunoprecipitation with antibodies against acetylated $\mathrm{H} 3$ and $\mathrm{H} 4$ as described in Material and Methods. DNA was purified from immunoprecipitates and subjected to amplification by PCR with primers directed to the core region of the GluR2 promoter. $a$, CA1, first lane, 100 and 200 bp size markers labeled in c; second lane, as expected, the size of the PCR product from genomic DNA (35 cycles) is 147 bp and is bracketed on either side by size markers. Omission of the histone antibodies showed negligible $P C R$ product (third and fourth lanes). Signal was prominent in control CA1 and greatly reduced at 24 and $48 \mathrm{hr}$ after ischemia. Each lane represents a different animal. $b$, CA3. Signal was prominent in both control and post-ischemic $C A 3$. C, A titration of genomic DNA shows that intensities of $P C R$ bands are proportional to the amount of input DNA ( $M$, size markers). Ischemia dramatically reduced the abundance of GluR2 promoter associated with acetylated histones $\mathrm{H} 3$ and $\mathrm{H} 4$ in samples from $\mathrm{CA} 1$, but not $\mathrm{CA} 3$, at 48 after global ischemia. no $\mathrm{Ab}$, Primary antibody omitted.

The finding that REST mRNA and protein are markedly increased in post-ischemic CA1 neurons suggests that REST is under transcriptional control. The finding that the increase in REST protein occurs before the increase in mRNA suggests additional regulation of REST expression at the translational or post-translational levels.

To quantify effects of global ischemia on REST protein abundance in the nuclear and cytosolic fractions of CA1, Western blot analysis was performed. Nuclear protein samples (extracts) isolated from the CA1 of control and experimental rats were subjected to gel electrophoresis and probed with the antibody directed to sequence within the N-terminal domain of the REST protein. Protein abundance was assessed by image analysis of band densities on Western blots. REST protein abundance in the nuclear fraction of the CA1 of control animals was very low (Fig. $3 a$ ). Global ischemia markedly increased REST protein abundance in the nuclear fraction of the hippocampal CA1, evident at $12 \mathrm{hr}$ ( to $424 \pm 56 \%$ of control; $p<0.01 ; n=5$ ), $24 \mathrm{hr}$ (to $328 \pm$ $85 \%$ of control; $n=3 ; p<0.05 ; n=5$ ), and $48 \mathrm{hr}$ (to $276 \pm 68 \%$ of control; $n=5$; Fig. $3 b$ ). REST protein expression was spatially restricted to the nucleus, in that it was not detectable in the corresponding cytosolic fractions of ischemic CAl at any time point examined (Fig. $3 a$ ). Together, these findings indicate that at early times after ischemic insult, REST protein expression is upregulated in CA1 neurons destined to die.

\section{Global ischemia represses GluR2 promoter activity in the CA1}

The results thus far indicate that ischemic insults dramatically upregulate REST mRNA and protein expression in the nuclei and cytoplasm of CA1 pyramidal neurons, but they do not provide information about REST functional activity. REST represses GluR2 promoter activity by deacetylation of core histone proteins associated with the GluR2 promoter (Huang et al., 1999). Because GluR2 is a known target of REST and is implicated in one of the death cascades triggered by global ischemia (Tanaka et al.,
2000), we examined the acetylation state of core histones over the GluR2 promoter. We reasoned that if REST mediates transcriptional repression of GluR2 expression in post-ischemic neurons, then induction of REST would promote deacetylation of histone proteins over the GluR2 promoter.

We used a ChIP assay to measure the abundance of acetylated core histone proteins $\mathrm{H} 3$ and $\mathrm{H} 4$ physically associated with the GluR2 proximal promoter in two subfields of the hippocampus, the vulnerable CA1 and the resistant CA3. After chromosomal DNA was sheared to $0.2-3 \mathrm{~kb}$, antibodies directed against acetylated $\mathrm{H} 3$ and $\mathrm{H} 4$ were used to immunoprecipitate chromatin. PCR with GluR2-specific primers directed to the promoter region was then used to monitor the amount of GluR2 DNA in the immunoprecipitates (Fig. 4a,b) and in genomic DNA as a control (Fig. 4c). In control CA1, a large abundance of GluR2 promoter was associated with acetylated $\mathrm{H} 3$ and $\mathrm{H} 4$ (Fig. $4 a$, control lanes). Induction of global ischemia dramatically reduced the abundance of GluR2 associated with acetylated $\mathrm{H} 4$ and $\mathrm{H} 3$ in the vulnerable CA1, evident at 24 and $48 \mathrm{hr}$ (Fig. $4 a$, ischemia lanes). In contrast, in CA3 global ischemia did not detectably alter the abundance of GluR2 associated with acetylated $\mathrm{H} 3$ or $\mathrm{H} 4$ as late as $48 \mathrm{hr}$ after ischemia (Fig. $4 \mathrm{~b}$ ). These findings suggest that global ischemia suppresses GluR2 transcriptional activity by a mechanism involving deacetylation of core histone proteins over GluR2 promoter and are consistent with a model in which REST acts via histone deacetylation to repress GluR2 gene expression.

\section{Global ischemia represses GluR2 mRNA and protein expression in CA1}

To examine insult-induced alterations in expression of REST and a REST target in the same experimental animals, we examined AMPAR GluR2 mRNA expression by in situ hybridization of brain sections at the level of the dorsal hippocampus from control and ischemic rats with an RNA probe directed to GluR2. As a control, we also examined ischemia-induced changes in expression of the GluR1 gene, which is not a target of REST. In control hippocampus, GluR2 mRNA expression was highly visible in the pyramidal cell layers of CA 1 and CA3 and in the granule cell layer of the dentate gyrus (Fig. 5a). GluR2 mRNA was not apparent in the stratum radiatum and stratum oriens of CA1 or in the stratum lucidum and stratum oriens of CA3. Global ischemia induced a marked, but cell-specific, reduction in GluR2 mRNA expression in the pyramidal cell layer of CA1, evident at $24 \mathrm{hr}$ (to $61.1 \pm 2.84 \%$ of control; $p<0.05 ; n=8$ ). GluR2 mRNA expression was markedly reduced at $48 \mathrm{hr}$ (to $38.24 \pm 3.36 \%$ of control; $p<0.01 ; n=12$ ) (Fig. 5b). The reduction in GluR2 mRNA expression was cell specific in that its expression was not altered in the granule cell layer of the dentate gyrus (Fig. 5b) or in the pyramidal cell layer of the CA3 (data not quantified, but see Fig. $5 a$ ). The ischemia-induced alteration in mRNA expression was subunit specific, in that GluR1 mRNA was unchanged at $48 \mathrm{hr}$ after ischemia, the only time point at which it was evaluated (data not shown). These findings confirm earlier studies (PellegriniGiampietro et al., 1992; Gorter et al., 1997; Tanaka et al., 2002) and illustrate that ischemia-induced upregulation of REST precedes GluR2 downregulation and that the two processes exhibit the same pattern of cell specificity. These findings, together with those illustrated in Figure 4, suggest that REST is functionally active in insulted neurons and implicate a role for RESTdependent transcriptional repression in ischemia-induced downregulation of GluR2.

We next examined the effects of global ischemia on GluR2 protein in CA1 by quantitative Western blot analysis. Protein 
a

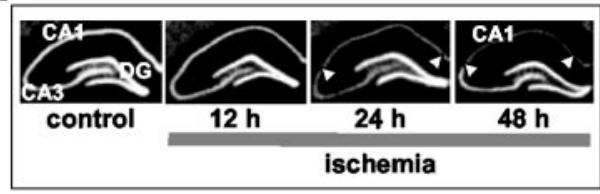

b

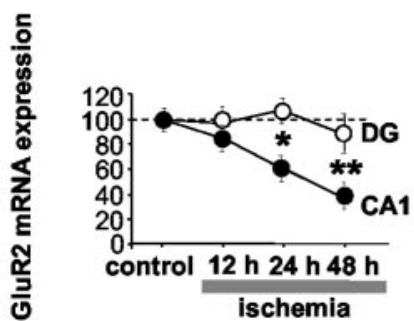

C

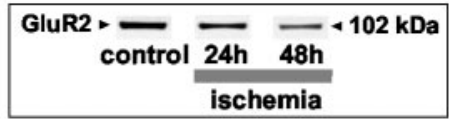

d

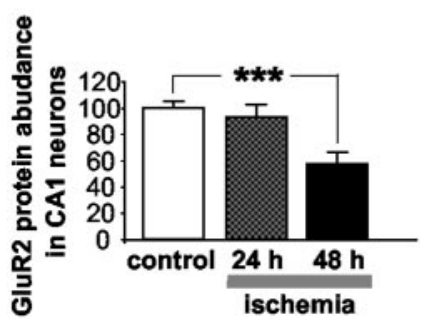

Figure 5. Global ischemia suppresses GluR2 mRNA and protein expression in CA1. $a$, Film autoradiograms of GluR2 mRNA expression, as detected by in situ hybridization, in the hippocampus of control $(n=4)$ and experimental rats at $12 \mathrm{hr}(n=8), 24 \mathrm{hr}(n=8)$, and $48 \mathrm{hr}$ $(n=12)$ after global ischemia. $b$, Quantitative analysis of GluR2 mRNA expression in the pyramidal cell layer of the $C A 1(C A 1, \bigcirc)$ and in the granule cell layer of the dentate gyrus (DG, O). Global ischemia induced a marked suppression of GluR2 mRNA expression specifically in the pyramidal neurons of the CA1 at $24 \mathrm{hr}$; suppression was maximal at $48 \mathrm{hr}$. No changes were detected in the DG or CA3. Mean optical densities are reported after normalization to the corresponding control value for a given region as indicated in Materials and Methods. Statistical significance was assessed by ANOVA followed by Newman-Keuls test $\left({ }^{*} p<0.05\right.$; $\left.{ }^{* *} p<0.01\right)$. $c$, Representative Western blots probed with a monoclonal antibody against a sequence within the N-terminal domain of the GluR2 subunit; $d$, relative GluR2 subunit abundance (defined as the ratio of band densities of experimental vs control samples) for protein samples isolated from the CA1 of control $(n=4)$ and experimental rats at $24 \mathrm{hr}(n=6)$ and $48 \mathrm{hr}(n=5)$ after ischemia. GluR2 abundance was determined from band densities for GluR2 after normalization to the band densities for actin, which served as a loading control. Relative GluR2 subunit abundance was markedly decreased in CA1 at $48 \mathrm{hr}$. Bars represent means \pm SEMs. Statistical significance was assessed by means of the Student's unpaired $t$ test $\left.{ }^{* * *} p<0.001\right)$.

samples from the CA1 and dentate gyrus of experimental and control rats were subjected to electrophoresis and probed with a monoclonal antibody directed to a sequence within the $\mathrm{N}$-terminal domain of the GluR2 subunit (Fig. 5c). Analysis of band densities indicated that global ischemia reduced GluR2 subunit abundance in CA1, evident at $48 \mathrm{hr}$ (to $57.2 \pm 8.7 \%$ of control; $p<0.001 ; n=5$ ) (Fig. $5 d$ ). The reduction was subfield specific, in that ischemia did not alter GluR2 subunit abundance in dentate gyrus as late as $48 \mathrm{hr}$ (data not shown). The reduction in GluR2 protein was subunit specific, in that global ischemia does not alter GluR1 protein expression (data not shown). These findings confirm previous studies (Opitz et al., 2000; Tanaka et al., 2002)' and indicate that REST expression occurs before GluR2 suppression and that both changes are specific to CA1 pyramidal neurons.

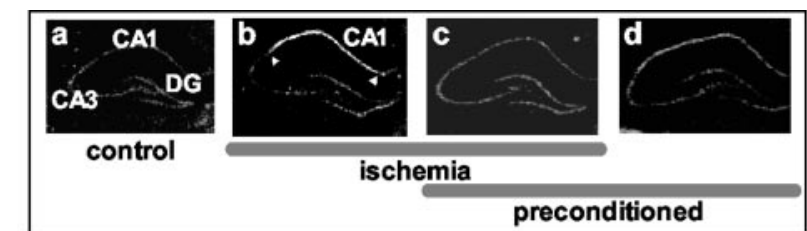

e

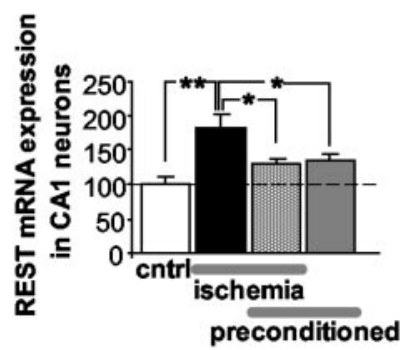

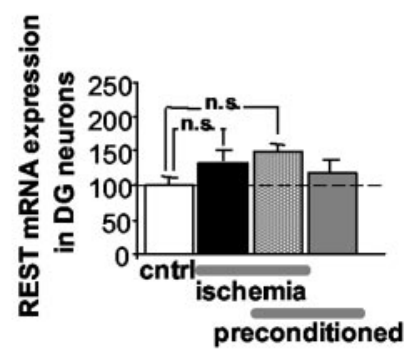

Figure 6. Ischemic preconditioning markedly attenuates ischemia-induced expression of REST in CA1. $a-d$, Film autoradiograms of REST mRNA expression detected by in situ hybridization with riboprobe 11 in the hippocampus of rats subjected to sham operation (a), global ischemia $(b)$, ischemic preconditioning followed by global ischemia $(c)$, and preconditioning followed by sham operation ( $d$ ) at $48 \mathrm{hr}$ after the last reperfusion. Quantitative analyses of REST mRNA expression in the pyramidal cell layer of the CA1 (e) and the granule cell layer of the DG $(f)$ for the four treatment groups. Global ischemia increased rREST mRNA expression in the hippocampal CA1 at $48 \mathrm{hr}(n=12)$ relative to that of controls $(n=3)$. Ischemic preconditioning, followed by global ischemia $(n=6)$, and ischemic preconditioning alone $(n=6)$ induced modest, but not statistically significant, increases in REST expression in the CA1. No significant changes were observed in the resistant DG. Mean optical densities are reported after normalization to the corresponding control value for a given region as indicated in Material and Methods. Bars represent means \pm SEMs. Statistical significance was assessed by ANOVA followed by Newman-Keuls test $\left({ }^{*} p<0.05 ;{ }^{* *} p<0.01\right)$. DG, Dentate gyrus; cntrl, control; n.s., not significant.

\section{Ischemic preconditioning acts upstream of REST to protect}

\section{CA1 neurons}

The results reported thus far indicate that ischemia increases REST expression and suppresses GluR2 promoter functional activity via a histone deacetylase-dependent mechanism, but they do not establish a causal relation between REST and GluR2 suppression. Ischemic preconditioning is a well known phenomenon in which brief, sublethal ischemic episodes afford robust protection of CA1 neurons against subsequent, more severe insults. Ischemic preconditioning attenuates ischemia-induced GluR2 downregulation (Tanaka et al., 2002) and thus provides an experimental paradigm in which to address this issue. We reasoned that, if REST were required for GluR2 suppression, preconditioning might act by blocking REST upregulation.

In control rats, REST mRNA was at low levels throughout the cell layers of the hippocampus (Figs. 1, 6a). Global ischemia markedly enhanced REST mRNA expression in the pyramidal cell layer of CA1 (Fig. 6b); REST mRNA was enhanced at $48 \mathrm{hr}$ (to $184 \pm 15.6 \%$ of control; $p<0.01 ; n=12$ ) (Fig. $6 e$ ). REST mRNA expression was not altered in CA3 or dentate gyrus (Figs. 1, Fig. $6 b, f)$. In contrast, in preconditioned rats, global ischemia induced a small, but nonsignificant, upregulation of REST mRNA in the CA1 (to $128.2 \pm 7.1 \%$ of control; $n=6$ ) (Fig. 6 e). Thus, at $48 \mathrm{hr}$ after ischemia, the degree of REST expression was virtually the same in preconditioned and naive animals (Fig. $6 a, c, e$ ). Preconditioning alone did not increase REST mRNA expression significantly in any hippocampal subfield $(n=6)$ (Fig. $6 d-f)$. The finding that preconditioning prevents REST upregulation and GluR2 downregulation is consistent with, but does not prove, a causal relation between REST and GluR2 suppression. 

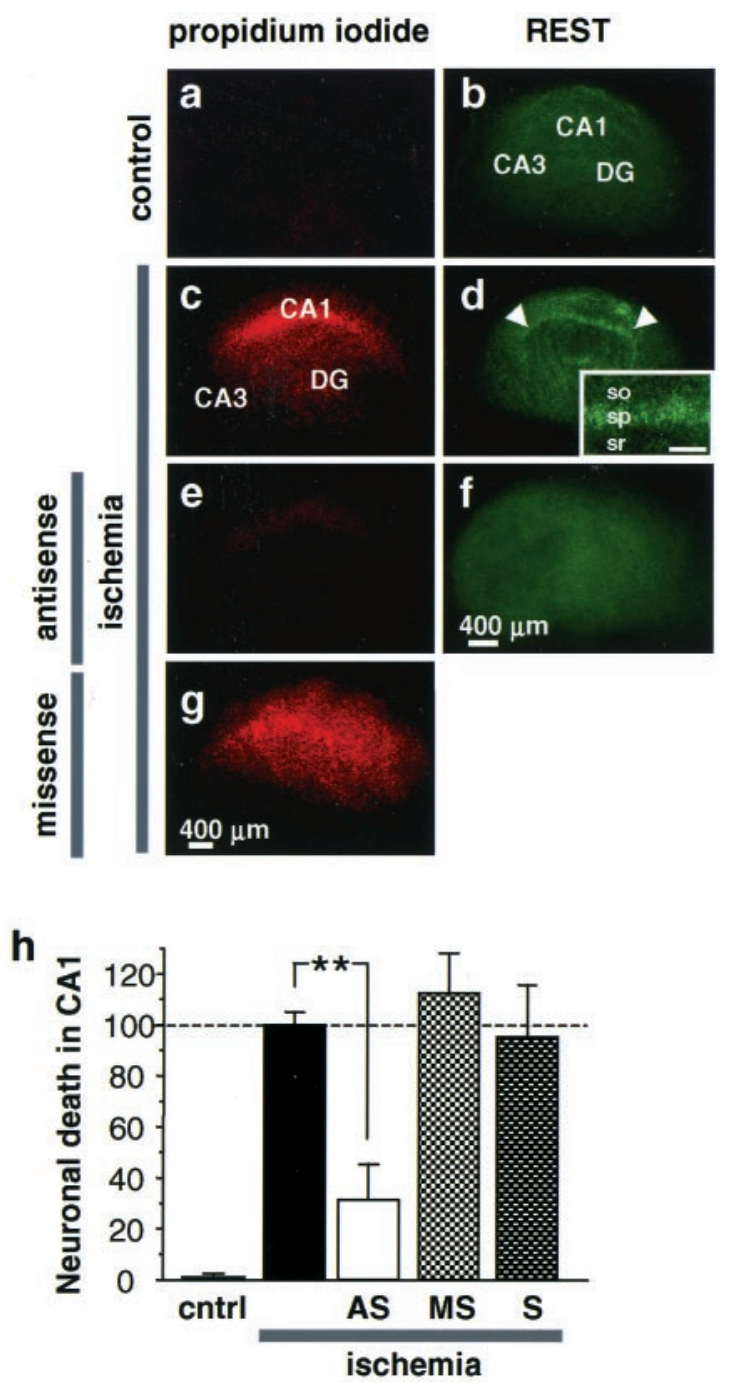

Figure 7. REST antisense blocks REST expression and rescues CA1 neurons from OGDinduced death. $a-g$, Propidium iodide labeling of organotypically cultured hippocampal slices. a, Control slice. c, Ischemic slice at $72 \mathrm{hr}$ after OGD (45 min). The pyramidal cell layer of CA1 exhibits intense propidium iodide labeling, indicative of cell death. $e$, REST antisense $(20 \mu \mathrm{m}$, administered immediately after OGD) prevents neuronal death. $g$, REST missense (20 $\mu \mathrm{M}$, administered immediately after $0 G D$ ) was without effect. $O G D$ caused extensive neuronal death in the pyramidal cell layer in CA1; REST antisense protected $\sim 70 \%$ of CA1 neurons. $b, d, 0 G D$ induced REST expression in CA1 pyramidal neurons, as assessed by immunofluorescence detected with the N-terminal antibody at $16 \mathrm{hr}$. $f$, REST antisense suppressed ischemia-induced REST expression. $h$, Quantitation of cell death. Propidium iodide fluorescence in the CA1 pyramidal cell layer, expressed as percentage of that in control slices at $72 \mathrm{hr}$ after $0 G D .{ }^{* *} p<0.01$. Scale bars: $a-g, 400 \mu \mathrm{m}$; inset, $100 \mu \mathrm{m}$. cntrl, Control; $A S$, antisense; MS, missense; S, sense.

\section{REST antisense prevents GluR2 suppression and rescues post-ischemic CA1 neurons}

To examine the impact of REST expression on ischemia-induced neuronal death, we performed knockdown experiments in hippocampal slice cultures with antisense oligodeoxynucleotides targeted to rat REST mRNA. Knockdown of transcription factors and other proteins has proven valuable in investigation of protein function in vivo and in vitro (for review, see Wahlestedt, 1994; Weiss et al., 1997). OGD in slice cultures provides an in vitro model of global ischemia and is ideal for administration of antisense oligonucleotides. Neuronal death was assessed quantitatively by propidium iodide uptake. OGD (45 min) induced death of CA1 pyramidal neurons, evident at $72 \mathrm{hr}($ Fig. $7 c, h)$. Neuronal death was selective in that it was spatially restricted to the CA1 pyramidal layer, was not detectable in the CA3, and was only occasionally detectable in the dentate gyrus (Fig. 7c). Neuronal death was delayed in that propidium iodide uptake was barely detectable at $24 \mathrm{hr}$ and maximal at $72 \mathrm{hr}$ (data not shown). Administration of an antisense oligodeoxynucleotide directed to the 5 ' end of rat REST mRNA immediately after OGD afforded robust protection of CA1 neurons $(n=9 ; p<0.01)$ (Fig. $7 e, h)$. In contrast, the corresponding missense $(n=9)$ (Fig. $7 g, h)$ and sense $(n=6)$ (Fig. $7 h)$ oligonucleotides, as well as antisense oligonucleotides directed to other regions of rat REST mRNA (data not shown), had little or no effect on neuronal survival. These findings provide evidence for the specificity of REST antisense in eliciting neuroprotection.

To examine the molecular mechanism by which REST antisense affords neuroprotection, we induced OGD in cultured hippocampal slices and examined REST expression by immunofluorescence. In control hippocampal slices, REST protein was at low abundance and spatially focused in the pyramidal cell layers of CA 1 and CA3 and in the granule cell layer of dentate gyrus (Fig. $7 b$ ). OGD induced a pronounced increase in REST protein in the cell bodies of CA1 pyramidal neurons (Fig. $7 d$ and inset). REST protein expression was cell-specific in that it was not detectably altered in the CA3 or dentate gyrus (Fig. 7d). REST antisense markedly suppressed REST expression in post-ischemic CA1 (Fig. $7 f$ ). These findings indicate that REST antisense affords neuroprotection by suppressing REST expression in neurons destined to die and implicate REST in ischemia-induced cell death.

To examine whether REST expression is causally related to GluR2 suppression, we induced OGD in slices and examined GluR2 protein expression by immunolabeling and Western blot analysis. In control hippocampal slices, GluR2 protein was at high abundance in the CA1 zone (Fig. 8a,d, CNTRL lane, e). OGD induced a significant decrease in GluR2 protein in CA1 (reduction to $69 \pm 7 \% ; n=5$ ) (Fig. $8 b, d$, ischemia lane, $e$ ). REST antisense prevented GluR2 suppression (Fig. $8 c$,d, ischemia $+A S$ lane, $e$ ). These findings implicate REST in ischemia-induced suppression of GluR2.

\section{Global ischemia induces highly selective, delayed death of CA1 pyramidal neurons}

To examine the spatial and temporal patterns of ischemiainduced neuronal damage, we performed histological analysis of brain sections at the level of dorsal hippocampus from animals killed at $48 \mathrm{hr}$ and $7 \mathrm{~d}$ after global ischemia or $7 \mathrm{~d}$ after sham operation. At $48 \mathrm{hr}$ after global ischemia, there was no histologically detectable neuronal death in any hippocampal subfield (Fig. $9 c, d, g)$. At $7 \mathrm{~d}$ after ischemia, the pyramidal cell layer of CA1 exhibited dramatic loss of neurons, whereas CA3 and dentate gyrus showed no damage (Fig. $9 e-g$ ).

\section{Discussion}

REST is ubiquitously expressed during embryogenesis and plays a strategic role in elaboration and specification of the neuronal phenotype by silencing a subset of neuron-specific genes in neural progenitors and non-neuronal cells (for review, see Schoenherr and Anderson, 1995). The existence and functional role of REST in mature neurons have remained obscure. The present study shows that, under physiological conditions, principal neurons of the hippocampus constitutively express REST protein at low abundance. Consistent with its role as a transcriptional repressor, REST expression is localized to the nuclei of hippocampal neurons. To our knowledge, these findings represent the first 

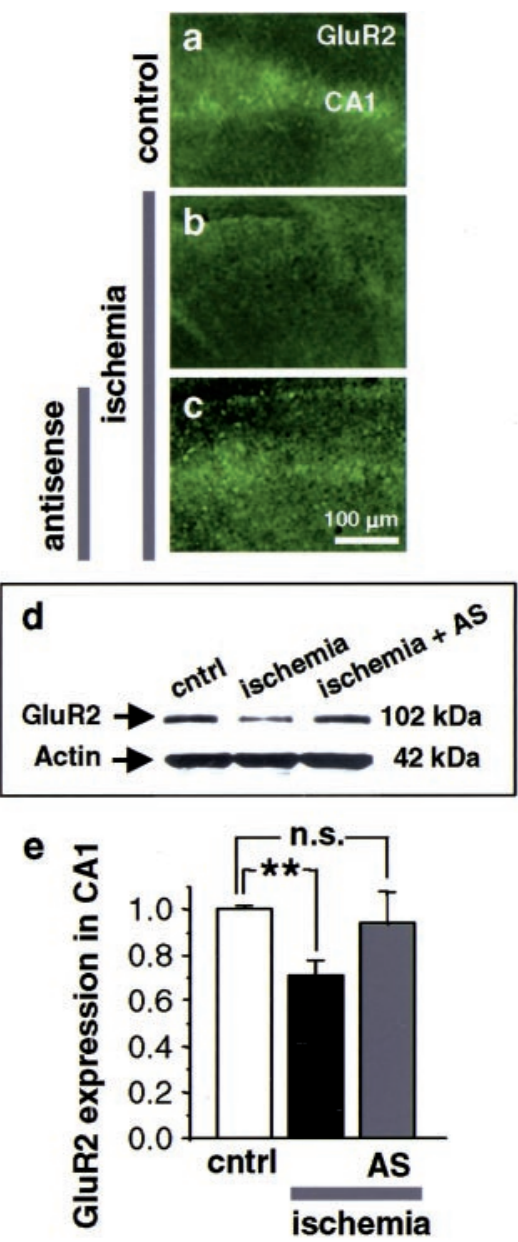

Figure 8. REST antisense blocks GluR2 suppression. $a-c$, GluR2 immunofluorescence in the CA1 of organotypically cultured hippocampal slices at $42 \mathrm{hr}$ after $\operatorname{OGD}(n=4)$. $a$, Control slice. GluR2 immunofluorescence is intense in the CA1 pyramidal cell layer. b, OGD induces GluR2 suppression in CA1 pyramidal neurons. C, REST antisense ( $20 \mu \mathrm{M}$, administered immediately after OGD) prevents ischemia-induced GluR2 suppression. $d$, Representative Western blot of samples from the CA1 of cultured slices probed with a GluR2 antibody. OGD decreased GluR2 protein expression in CA1 at $48 \mathrm{hr}$ (OGD lane) $(n=9)$. REST antisense ( $20 \mu \mathrm{m}$, administered immediately after OGD) blocked GluR2 downregulation (OGD + AS lane) $(n=3)$. REST sense ( $20 \mu \mathrm{M}$, administered immediately after OGD) was without effect (OGD $+S$ ). $e$, Quantitation of GluR2 protein expression, assessed by Western blot analysis. Band densities were normalized to those for actin. ${ }^{* *} p<0.01$. Scale bar: (in c) $a-c, 100 \mu \mathrm{m}$.

demonstration of REST protein expression by neurons in vivo. Findings in the present study are consistent with observations that REST mRNA is expressed at low abundance by central neurons of adult rat (Palm et al., 1998). Alternative RNA splicing of REST generates at least five truncated isoforms, two of which are neuron specific (Palm et al., 1998) and may function as dominant negatives or "anti-silencers" when expressed in neuronal cell lines (Shimojo et al., 1999). The persistent expression of REST mRNA and low levels of REST protein could reflect a role for REST in the fine-tuning of target genes implicated in activitydependent synaptic plasticity (Shimojo et al., 1999) and specification of different neuronal cell types.

The present study also shows that ischemic insults trigger a pronounced upregulation of REST mRNA and protein in selectively vulnerable CA1 neurons. Moreover, acute knockdown of the REST gene by administration of antisense oligonucleotides to hippocampal slices rescues CA1 neurons from OGD-induced death. These findings indicate a causal relation between REST
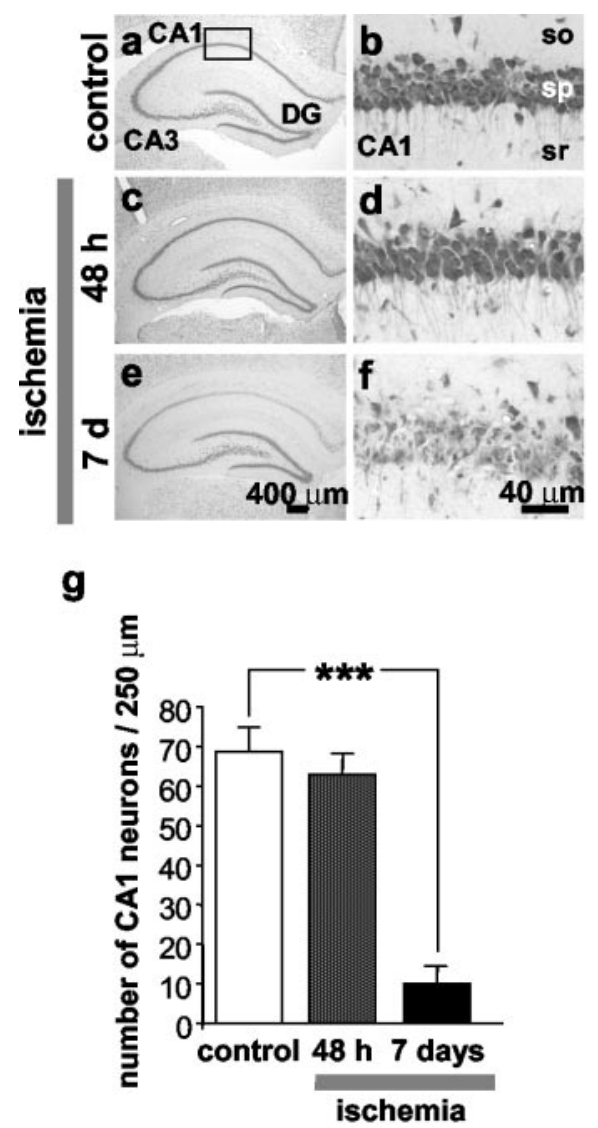

Figure 9. Global ischemia induces selective, delayed neuronal death in hippocampal CA1. $a-f$, Toluidine blue staining of coronal brain sections at the level of the dorsal hippocampus from control $(a, b)(n=5)$ and experimental male rats subjected to global ischemia at $48 \mathrm{hr}(c$, d) $(n=9)$ and $7 \mathrm{~d}(e, f)(n=5)$ after ischemia. Control animals were killed at $7 \mathrm{~d}$ after sham operation. At $48 \mathrm{hr}$ after global ischemia, there was no histologically detectable neuronal death in any hippocampal subfield. At $7 \mathrm{~d}$ after ischemia, the pyramidal cell layer of CA1 exhibited dramatic loss of neurons, whereas CA 3 and dentate gyrus showed no damage. Scale bars: $a, c, e$, $400 \mu \mathrm{m} ; b, d, f, 40 \mu \mathrm{m} . g$, Quantitation of cell counts from brain sections illustrated in $a-f$. To assess hippocampal injury, the number of surviving neurons per $250 \mu \mathrm{m}$ length in the pyramidal cell layer of the medial CA1 was counted under a light microscope at $40 \times$ magnification in sections. Neuronal counts from a minimum of four microscopic sections per animal were analyzed; comparisons among group means were made using the Student's t test ( $\left.{ }^{* * *} p<0.001\right)$.

expression and neuronal death. Our findings are consistent with observations that seizures markedly upregulate REST mRNA (Palm et al., 1998) and suppress GluR2 promoter activity in vulnerable hippocampal neurons (Huang et al., 2002) and suggest that REST-dependent silencing of the AMPAR GluR2 gene may be a broad mechanism of insult-induced delayed neuronal death. Accordingly, perturbation of REST expression during embryogenesis causes cellular apoptosis, aberrant differentiation and patterning, and lethality (Chen et al., 1998).

Consistent with induction of REST, ischemia induces deacetylation of core histone proteins over the GluR2 promoter, indicative of reduced GluR2 promoter activity, and suppresses GluR2 mRNA and protein expression in CA1 neurons. Acute knockdown of the REST gene by administration of REST antisense to slice cultures prevents OGD-induced GluR2 downregulation. These findings indicate a causal relation between REST induction and GluR2 suppression in post-ischemic neurons. Accordingly, ischemic preconditioning, a well established neuroprotective strategy, significantly attenuated REST induction and GluR2 downregulation. Together, these observations implicate REST- 
dependent gene silencing and chromatin remodeling in transcriptional repression of GluR2 in post-ischemic neurons. These findings, however, do not rule out additional mechanisms of transcriptional repression such as altered DNA methylation of the cytosine-guanosine $(\mathrm{CpG})$ dinucleotide island present in the GluR2 promoter after ischemic insult (Huang et al., 1999).

Global ischemia is a neuronal insult that induces delayed, selective death of CA1 pyramidal neurons. The molecular mechanisms underlying ischemia-induced cell death are unclear. Our findings that ischemic insults trigger REST expression, and that REST knockdown rescues CA1 neurons from cell death, strongly implicate REST in the signaling cascades between neuronal insult and cell death. Considerable evidence also implicates a role for AMPARs in ischemia-induced neuronal death (Tanaka et al., 2000). Because AMPAR-mediated $\mathrm{Ca}^{2+}$ influx is implicated in several models of neuronal ischemia, and the GluR2 subunit governs $\mathrm{Ca}^{2+}$ permeability of AMPARs, its suppression would be expected to influence neuronal survival. Our finding in the present study that REST suppresses GluR2 expression in CA1 neurons provides further support for a role for REST in the signaling cascades from neuronal insult to cell death. Although not addressed in the present study, other REST targets such as neurotrophic factor BDNF could also play a positive or negative role in neuronal death.

Recent advances suggest that a subset of cellular genes implicated in genetic and acquired neurological disorders encode proteins essential to neural patterning and neurogenesis (Mehler and Gokhan, 2001). Dysregulation of REST and its target genes is implicated in the pathogenesis of Down's syndrome (Bahn et al., 2002), Alzheimer's disease (Okazaki et al., 1995), and some medulloblastoma-derived cells (Lawinger et al., 2000). To our knowledge, our study represents the first example of injuryinduced induction of a master transcriptional regulator gene and its protein expression critical to neural differentiation in adult neurons. Derepression of REST in mature neurons may be a broad mechanism of insult-induced neuronal death.

\section{References}

Andria ML, Simon EJ (2001) Identification of a neurorestrictive suppressor element (NRSE) in the human mu-opioid receptor gene. Brain Res Mol Brain Res 91:73-80.

Bahn S, Mimmack M, Ryan M, Caldwell MA, Jauniaux E, Starkey M, Svendsen CN, Emson P (2002) Neuronal target genes of the neuron-restrictive silencer factor in neurospheres derived from fetuses with Down's syndrome: a gene expression study. Lancet 359:310-315.

Ballas N, Battaglioli E, Atouf F, Andres ME, Chenoweth J, Anderson ME, Burger C, Moniwa M, Davie JR, Bowers WJ, Federoff HJ, Rose DW, Rosenfeld MG, Brehm P, Mandel G (2001) Regulation of neuronal traits by a novel transcriptional complex. Neuron 31:353-365.

Bessis A, Salmon AM, Zoli M, Le Novere N, Picciotto M, Changeux JP (1995) Promoter elements conferring neuron-specific expression of the beta 2 -subunit of the neuronal nicotinic acetylcholine receptor studied in vitro and in transgenic mice. Neuroscience 69:807-819.

Bowie D, Mayer ML (1995) Inward rectification of both AMPA and kainate subtype glutamate receptors generated by polyamine-mediated ion channel block. Neuron 15:453-462.

Burnashev N, Monyer H, Seeburg PH, Sakmann B (1992) Divalent ion permeability of AMPA receptor channels is dominated by the edited form of a single subunit. Neuron 8:189-198.

Chen H, Tini M, Evans RM (2001) HATs on and beyond chromatin. Curr Opin Cell Biol 13:218-224.

Chen ZF, Paquette AJ, Anderson DJ (1998) NRSF/REST is required in vivo for repression of multiple neuronal target genes during embryogenesis. Nat Genet 20:136-142.

Chong JA, Tapia-Ramirez J, Kim S, Toledo-Aral JJ, Zheng Y, Boutros MC, Altshuller YM, Frohman MA, Kraner SD, Mandel G (1995) REST: a mammalian silencer protein that restricts sodium channel gene expression to neurons. Cell 80:949-957.

Donevan SD, Rogawski MA (1995) Intracellular polyamines mediate in ward rectification of $\mathrm{Ca}\left({ }^{2+}\right)$-permeable alpha-amino-3-hydroxy-5methyl-4-isoxazolepropionic acid receptors. Proc Natl Acad Sci USA 92:9298-9302.

Fan D, Grooms SY, Araneda RC, Johnson AB, Dobrenis K, Kessler JA, Zukin RS (1999) AMPA receptor protein expression and function in astrocytes cultured from hippocampus. J Neurosci Res 57:557-571.

Fitzgerald LW, Deutch AY, Gasic G, Heinemann SF, Nestler EJ (1995) Regulation of cortical and subcortical glutamate receptor subunit expression by antipsychotic drugs. J Neurosci 15:2453-2461.

Fitzgerald LW, Ortiz J, Hamedani AG, Nestler EJ (1996) Drugs of abuse and stress increase the expression of GluR1 and NMDAR1 glutamate receptor subunits in the rat ventral tegmental area: common adaptations among cross-sensitizing agents. J Neurosci 16:274-282.

Friedman LK, Pellegrini-Giampietro DE, Sperber EF, Bennett MVL, Moshe SL, Zukin RS (1994) Kainate-induced status epilepticus alters glutamate and $\mathrm{GABA}_{\mathrm{A}}$ receptor gene expression in adult rat hippocampus: an in situ hybridization study. J Neurosci 14:2697-2707.

Gorter JA, Petrozzino JJ, Aronica EM, Rosenbaum DM, Opitz T, Bennett MVL, Connor JA, Zukin RS (1997) Global ischemia induces downregulation of GluR2 mRNA and increases AMPA receptor-mediated $\mathrm{Ca}^{2+}$ influx in hippocampal CA1 neurons of gerbil. J Neurosci 17:6179-6188.

Hollmann M, Hartley M, Heinemann S (1991) $\mathrm{Ca}^{2+}$ permeability of KAAMPA-gated glutamate receptor channels depends on subunit composition. Science 252:851-853.

Howland DS, Hemmendinger LM, Carroll PD, Estes PS, Melloni Jr RH, DeGennaro LJ (1991) Positive- and negative-acting promoter sequences regulate cell type-specific expression of the rat synapsin I gene. Brain Res Mol Brain Res 11:345-353.

Huang Y, Myers SJ, Dingledine R (1999) Transcriptional repression by REST: recruitment of Sin $3 \mathrm{~A}$ and histone deacetylase to neuronal genes. Nat Neurosci 2:867-872.

Huang Y, Doherty JJ, Dingledine R (2002) Altered histone acetylation at glutamate receptor 2 and brain-derived neurotrophic factor genes is an early event triggered by status epilepticus. J Neurosci 22:8422-8428.

Kraner SD, Chong JA, Tsay HJ, Mandel G (1992) Silencing the type II sodium channel gene: a model for neural-specific gene regulation. Neuron 9:37-44.

Lawinger P, Venugopal R, Guo ZS, Immaneni A, Sengupta D, Lu W, Rastelli L, Marin Dias CA, Levin V, Fuller GN, Echelard Y, Majumder S (2000) The neuronal repressor REST/NRSF is an essential regulator in medulloblastoma cells. Nat Med 6:826-831.

Li L, Suzuki T, Mori N, Greengard P (1993) Identification of a functional silencer element involved in neuron-specific expression of the synapsin I gene. Proc Natl Acad Sci USA 90:1460-1464.

Liu SQJ, Cull-Candy SG (2000) Synaptic activity at calcium-permeable AMPA receptors induces a switch in receptor subtype. Nature 405:454-458.

Mehler MF, Gokhan S (2001) Developmental mechanisms in the pathogenesis of neurodegenerative diseases. Prog Neurobiol 63:337-363.

Mieda M, Haga T, Saffen DW (1997) Expression of the rat m4 muscarinic acetylcholine receptor gene is regulated by the neuron-restrictive silencer element/repressor element 1. J Biol Chem 272:5854-5860.

Mori N, Schoenherr C, Vandenbergh DJ, Anderson DJ (1992) A common silencer element in the SCG10 and type II Na+ channel genes binds a factor present in nonneuronal cells but not in neuronal cells. Neuron 9:45-54.

Myers SJ, Peters J, Huang Y, Comer MB, Barthel F, Dingledine R (1998) Transcriptional regulation of the GluR2 gene: neural-specific expression, multiple promoters, and regulatory elements. J Neurosci 18:6723-6739.

Nair SM, Werkman TR, Craig J, Finnell R, Joels M, Eberwine JH (1998) Corticosteroid regulation of ion channel conductances and mRNA levels in individual hippocampal CA1 neurons. J Neurosci 18:2685-2696.

Okazaki T, Wang H, Masliah E, Cao M, Johnson SA, Sundsmo M, Saitoh T, Mori N (1995) SCG10, a neuron-specific growth-associated protein in Alzheimer's disease. Neurobiol Aging 16:883-894.

Opitz T, Grooms SY, Bennett MVL, Zukin RS (2000) Remodeling of alphaamino-3-hydroxy-5-methyl-4-isoxazole-propionic acid receptor subunit composition in hippocampal neurons after global ischemia. Proc Natl Acad Sci USA 97:13360-13365. 
Palm K, Belluardo N, Metsis M, Timmusk T (1998) Neuronal expression of zinc finger transcription factor REST/NRSF/XBR gene. J Neurosci 18:1280-1296.

Paquette AJ, Perez SE, Anderson DJ (2000) Constitutive expression of the neuron-restrictive silencer factor (NRSF)/REST in differentiating neurons disrupts neuronal gene expression and causes axon pathfinding errors in vivo. Proc Natl Acad Sci USA 97:12318-12323.

Passafaro M, Piech V, Sheng M (2001) Subunit-specific temporal and spatial patterns of AMPA receptor exocytosis in hippocampal neurons. Nat Neurosci 4:917-926.

Pellegrini-Giampietro DE, Bennett MVL, Zukin RS (1991) Differential expression of three glutamate receptor genes in developing rat brain: an in situ hybridization study. Proc Natl Acad Sci USA 88:4157-4161.

Pellegrini-Giampietro DE, Zukin RS, Bennett MVL, Cho S, Pulsinelli WA (1992) Switch in glutamate receptor subunit gene expression in CA1 subfield of hippocampus following global ischemia in rats [Erratum (1993) 90:780]. Proc Natl Acad Sci USA 89:10499-10503.

Pollard H, Heron A, Moreau J, Ben-Ari Y, Khrestchatisky M (1993) Alterations of the GluR-B AMPA receptor subunit flip/flop expression in kainate-induced epilepsy and ischemia. Neuroscience 57:545-554.

Prince HK, Conn PJ, Blackstone CD, Huganir RL, Levey AI (1995) Downregulation of AMPA receptor subunit GluR2 in amygdaloid kindling. J Neurochem 64:462-465.

Pulsinelli WA, Brierley JB (1979) A new model of bilateral hemispheric ischemia in the unanesthetized rat. Stroke 10:267-272.

Schoch S, Cibelli G, Thiel G (1996) Neuron-specific gene expression of synapsin I. Major role of a negative regulatory mechanism. J Biol Chem 271:3317-3323

Schoenherr CJ, Anderson DJ (1995) Silencing is golden: negative regulation in the control of neuronal gene transcription. Curr Opin Neurobiol 5:566-571.

Schoenherr CJ, Paquette AJ, Anderson DJ (1996) Identification of potential target genes for the neuron-restrictive silencer factor. Proc Natl Acad Sci USA 93:9881-9886.

Shimojo M, Paquette AJ, Anderson DJ, Hersh LB (1999) Protein kinase A regulates cholinergic gene expression in PC12 cells: REST4 silences the silencing activity of neuron-restrictive silencer factor/REST. Mol Cell Biol 19:6788-6795.

Stoppini L, Buchs PA, Muller D (1991) A simple method for organotypic cultures of nervous tissue. J Neurosci Methods 37:173-182.

Swanson GT, Kamboj SK, Cull-Candy SG (1997) Single-channel properties of recombinant AMPA receptors depend on RNA editing, splice variation, and subunit composition. J Neurosci 17:58-69.

Tanaka H, Grooms SY, Bennett MVL, Zukin RS (2000) The AMPAR subunit GluR2: still front and center-stage. Brain Res 886:190-207.

Tanaka H, Calderone A, Jover T, Grooms SY, Yokota H, Zukin RS, Bennett MVL (2002) Ischemic preconditioning acts upstream of GluR2 downregulation to afford neuroprotection in the hippocampal CA1. Proc Natl Acad Sci USA 99:2362-2367.

Verdoorn TA, Burnashev N, Monyer H, Seeburg PH, Sakmann B (1991) Structural determinants of ion flow through recombinant glutamate receptor channels. Science 252:1715-1718.

Wada E, Wada K, Boulter J, Deneris E, Heinemann S, Patrick J, Swanson LW (1989) Distribution of alpha 2, alpha 3, alpha 4, and beta 2 neuronal nicotinic receptor subunit mRNAs in the central nervous system: a hybridization histochemical study in the rat. J Comp Neurol 284:314-335.

Wahlestedt C (1994) Antisense oligonucleotide strategies in neuropharmacology. Trends Pharmacol Sci 15:42-46.

Weiss B, Davidkova G, Zhang SP (1997) Antisense strategies in neurobiology. Neurochem Int 31:321-348.

Wood IC, Roopra A, Buckley NJ (1996) Neural specific expression of the m4 muscarinic acetylcholine receptor gene is mediated by a RE1/NRSE-type silencing element. J Biol Chem 271:14221-14225. 